\title{
The Rise of Platform-based Models and its Impact on Banking and Financial Services
}

\section{Sanjib Dutta}

Research Lead, ICFAI Business School Hyderabad, Hyderabad, Telangana, India

*Correspondence: Sanjib Dutta, sanjibdutta174@gmail.com

\begin{abstract}
The banking and financial services industry is getting disintermediated. The platform model is disrupting almost every industry and banking and financial services industry is not an exception. Platform players are giving serious competition to the traditional banking and financial services players. The disintermediation of the vertically integrated value chain is altering the industry landscape across geographies. Amazon, Google, Apple, Facebook in North America and Alibaba, Baidu and Tencent in China are acquiring new customers and offering products and services on their ecosystem as Orchestrators, while their partners are taking advantage of the ecosystem and creating competitive advantage through their products and services. The disruption of the traditional vertically integrated industry structure looks real and may have reaching consequences. The cost advantage of the platform model will lure firms to be partners in this model. The network effect of the platform model makes it a sustainable business model with long term revenue opportunities. Traditional firms may need to alter the way they did business to survive the onslaught from platform players.
\end{abstract}

Keywords: Banking, Financial services, Disintermediation, Platform, Platform model, Platform banking, Banking value chain, Vertical integration, Platform integrator, Platform provider, Platform specialist, Platform orchestrator

\section{ARTICLE INFORMATION}

Author(s): Sanjib Dutta

Received: 19 Oct, 2020; Accepted: 16 Nov, 2020; Published: 14 Dec 2020; e-ISSN: 2347-4696;

Paper Id: BMN-IJBMR-2020-13;

Citation: doi.org/10.37391/IJBMR.080408

Webpage-link: https://ijbmr.forexjournal.co.in/archive/volume-8/ijbmr-080408.html

\section{INTRODUCTION}

Google has recently announced that it will offer smart checking accounts. Google planned to offer this service in 2020 in partnership with Citigroup. This announcement made by Google in November 2019 is the latest among many other such announcements made by Big Tech Platform players to move into banking and financial services. Tech players such as Facebook, Apple and Amazon have already got into credit cards, payments and loans which were earlier dominated by traditional banks and financial services players (Google set to offer banking current accounts [1].

This paper is an attempt to understand the disintermediation happening in the banking and financial services industry due to the entry of tech-based platform players. The paper looks at the various disruptions in the banking and financial services industry triggered by the platform players. It looks at the available literature to understand the developments captured by various researchers.

\section{LITERATURE REVIEW AND THEORETICAL FRAMEWORK}

In the mid-1990s, the beginning of internet era led to the start of disintermediation of banking and the traditional banking model of using predominantly cash and cheques for banking transactions began losing their importance. Branch banking was expected to collapse due to new-age internet banking resulting in lower operating costs [2].

The disintermediation of banking and financial services was visible in $2000 \mathrm{~s}$, with financial technology firms (FinTechs) and players from other industries such as technology (Facebook, Apple, Amazon in North America and Alibaba in China) and search engines (Google in North America, Baidu and Tencent in China) getting into the banking and financial services space. These technology platform players started disrupting banking and financial services space like never before and challenged the domination of traditional banks and financial services, mostly in North America, Western Europe and China [2].

The platform technology players mentioned above are global in the true sense of the term and are much younger than the banks and financial services players with whom they compete. Facebook has more than $80 \%$ of its daily active customers from outside North America. With large geographical footprint and huge loyal customer base, these players are ideally suited to enter core banking space in future. These players have already made inroads into the payments space with e-wallets, apps which enable peer-to-peer (P2P) money transfers and mobile payment solutions. They could soon expand into core banking areas such as deposits and lending with the help of $\mathrm{P} 2 \mathrm{P}$ platforms [2].

FinTechs are already making their presence felt in consumer lending and payments space. FinTechs have invested more than $\$ 10$ billion since the year 2000 in consumer lending and payments. Some of these FinTechs, which include P2P lenders and money transfer firms, aim to disintermediate banks across the banking and payments value chain while others such as mobile payment solution players target specific components of 
the value chain [2].

In the Financial Services industry, the impact of innovations is the most where firms employed business models that are platform based. Credit evaluation and loan origination are being transformed by new lending platforms. As consumer turn to alternative platforms, traditional deposits and investment products offered by banks and financial services firm will get eroded. Also, crowd-funding platforms are making capital raising easy. Payment solutions which enable customers to do direct payment on their platform will displace the use of credit cards. Digital wallets that consolidate digital payment platforms will make financial institutions lose control over their customers' transaction experience [3].

Figure 1 below shows value chain components in banking and financial services from an asset management perspective. Almost every component of the value chain in asset management is getting disrupted by platform players. Banks have to decide which components of the value chain to focus on, which customer segments to target, and which products and geographies to have presence in to survive the onslaught of platform players [2].

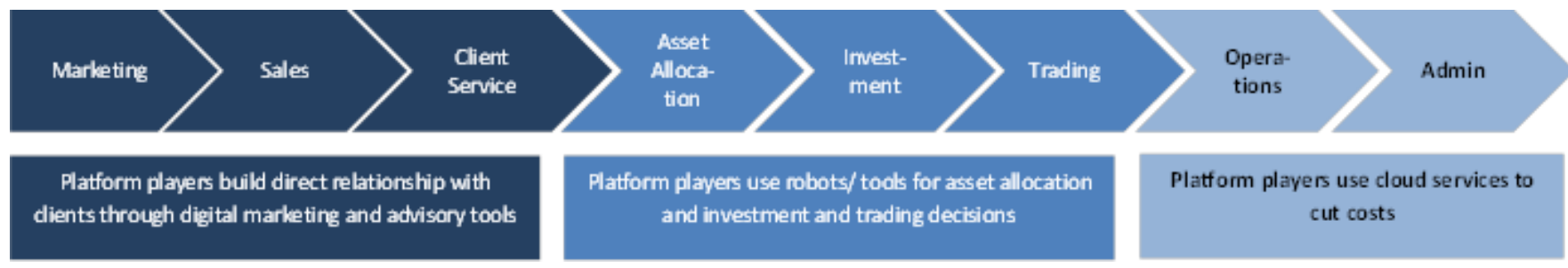

Figure 1: Value Chain Components - Banking and Financial Services [2].

The risk of disintermediation for banks is real. Banks are at the risk of losing $30 \%$ of revenues as digital natives who are used to personalized experiences in their day-to-day transactions expect their banks to provide similar experiences. Investment in FinTech is expanding and it reached $\$ 22$ billion globally in 2015, up from $\$ 13$ billion in 2014 and $\$ 5$ billion in 2013. The highest growth was in Asia Pacific where the investment quadrupled to $\$ 4$ billion. Banks needs to transform them to survive the onslaught of platform players. Traditional banks can partner with players outside the banking and financial services industry to build an ecosystem that can help explore alternative revenue streams [4].

It is not only FinTechs that are taking care of customers' banking needs but also third-party aggregators who are driving the customers to manage their banking requirements by visiting one platform, thereby removing any direct contact with banks. Banks and financial services firms need to establish a portfolio of digital platforms to offer digital financial solutions [4].

Non-banks are emerging as new competitors for traditional banks. New competitors to banks are online investment communities, P2P business models. The new competitors position themselves at different places within the banking value chain and can challenge the traditional banks' market share in areas such as investments and financing. These players have the potential to completely disintermediate traditional banking [5].

In 2016, Banks had ROE of $8.6 \%$. By orchestrating a basic "ecosystem" strategy, which involves building partnerships and monetizing data, banks can catapult their ROE to about $10 \%$. Banks can also create their own platforms which will increase their ROE to about 14 percent [6].
Traditionally, banks operated in a vertically integrated value chain - from production to sales, distribution and servicing. Though banks had the option of outsourcing many components, but the cost structure remained mostly fixed and bloated. The threat of disintermediation has made the traditional way of banking unsustainable though highly regulated, disruptive innovation in banking ensured that they found a way to the marketplace. Banks have to reassess their vertically integrated banking models and consider platformased business models [7].

The imminent threat of disintermediation makes the traditional operating model unsustainable. Traditional banks do not have many weapons to fight the onslaught of platform-based banking. One such weapon is Open Banking which has become a buzzword. Open Banking is a platform-based business approach. In this approach, data, processes, and business functionalities are shared by an ecosystem of banks, customers and third-party players, FinTechs and partners [8].

The bank of tomorrow will be a "customer-centered platform." Retail customers want banks to enable integrating ecommerce, social media and retail payments. They also want banks to enable switching seamlessly across digital platforms. Banks were historically not used to such environment as they were under heavy compliance obligations. Traditionally, banks invested more in security and not so much in optimizing user experience. That's going to change in the platform environment [9].

Research conducted by McKinsey analysts in 2018 shows that for several years in the past, banking returns were between 8 and 10 percent. The best way to improve margins, according to these researchers is to embrace the ecosystem environment. This can be done as the traditional banks have inherent advantages such as customer trust, regulatory knowledge, a 
big customer base, and unexploited data. There are two ways of doing it: either join the business ecosystem and take advantage of the network effect or banks with stronger digital capabilities can even build an ecosystem and have other banking and non-banking players join the ecosystem [10].

A study conducted by some researchers in 2018 has gone to the extent of identifying the areas where platform business models will impact banks over the next three years. They are of the opinion that the impact will be the highest on revenues followed by profitability, and customer satisfaction [11]. These researchers suggest that the platform-oriented visionary banks are in a better position to compete with platform players. Their research shows that adoption of platform business models will lead to significant benefits for customers as well as for the banks themselves [10].

Alibaba, Amazon, Facebook, Google and Tencent known as the "Big Techs" have grown rapidly over the past two decades due to their business model which enables direct interaction among users. These tech firms have huge consumer data which enables them to offer services driven by the network effects which again creates for more activity for the users, thereby generating more data. Piggybacking on the network activities, these tech firms got into financial services which include payments, money management and lending. The major advantage for these tech firms is their low-cost operations and their operations can be easily scaled up to provide financial services to the unbanked population [12].

By using technologies such as big data and analytics, these firms can profile the risk appetite of consumers and provide financial services in tune with the user profiles. This ensures that consumers' repayment is high and at the same time the need for collateral to ensure repayment is low [12].

\begin{tabular}{|l|l|c|c|c|}
\hline \multirow{2}{*}{ BigTech Firm } & \multirow{2}{*}{ Geography } & \multicolumn{3}{|c|}{ Financial Service Offerings } \\
\hline & & Payments & MMF & Lending \\
\hline $\begin{array}{l}\text { Alibaba/Alipay, } \\
\text { Tencent }\end{array}$ & China & $\checkmark$ & $\checkmark$ & $\checkmark$ \\
\hline Baidu & China & $\checkmark$ & $\checkmark$ & $\checkmark$ \\
\hline $\begin{array}{l}\text { Vodafone M- } \\
\text { Pesa }\end{array}$ & Africa & $\checkmark$ & & $\checkmark$ \\
\hline GO-Jek & $\begin{array}{l}\text { Southeast } \\
\text { Asia }\end{array}$ & $\checkmark$ & & \\
\hline Grab & $\begin{array}{l}\text { Southeast } \\
\text { Asia }\end{array}$ & $\checkmark$ & $\checkmark$ & $\checkmark$ \\
\hline Google & Global & $\checkmark$ & & $\checkmark$ \\
\hline Amazon, PayPal & Global & $\checkmark$ & & $\checkmark$ \\
\hline $\begin{array}{l}\text { Apple, } \\
\text { Facebook, } \\
\text { Microsoft }\end{array}$ & Global & $\checkmark$ & & \\
\hline *in early 2019 & \multicolumn{5}{|l}{} \\
\hline
\end{tabular}

Table 1: Financial Service Offerings of Select BigTech Firms [12].

Table 1 above shows the various the financial service offerings of BigTech/Platform firms in different geographies. Most of the BigTech firms entered the financial services industry by offering payment solutions. Some of the most popular ones include Alipay from Alibaba in China, WePay also in China, M-Pesa in Africa and PayPal, a publicly traded company in US, earlier owned by eBay [12]. These firms have also entered the money market fund (MMF) due to their brand recognition and wide customer network. Alibaba's YueBao is the world's top MMF with assets worth $\$ 170$ billion [13].

Some of these BigTech firms such as Alibaba which have their ecommerce platforms have also entered into the lending space, mostly to SMEs and consumers. The lending footprint of these firms is small as of now, but through options such as online banking and partnership with other banks, these firms can increase their scope of the lending business [12].

Regulatory compliance, cyber-security, and absence of trust in ecosystem partners inhibit banks' adoption of platform business models [14]. With increasing trust between partners, banks can act as conduit of products and services which can lead to increase in customer experience [14]. In a survey conducted by IBM Institute of Business Value covering 800 plus global banking leaders, $80 \%$ say Profitability is the biggest benefit of adopting platform model followed by Innovation and access to markets [14].

Within the platform business model for banks, four distinct roles are available. These are that of Integrators, Providers, Specialists and Orchestrators. Integrators bring together products and services of third-party offerings. For e.g. FinTechs leverage open APIs to innovate. Providers develop and provision end-to-end products and services and Specialists focus on specific banking process activities. Orchestrators allow the platform members to interact and create value for members [14].

In developed markets, platform players have forayed into financial services. For example, Apple has launched Apple Card, and Facebook has launched Calibra, a wallet for its crypto-currency Libra, and Amazon has entered SME lending [15].

Digital platforms that are an essential member in sharing economy are challenging the traditional companies. Digital platforms have high access to data which reduces information asymmetry and leads to lower customer acquisition cost and full customization [16].

A Bain \& Company retail banking survey shows that traditional banks cannot keep up with technology firms in five service areas such as quality, time savings, simplification, anxiety reduction and being a good investment for future generations. The research shows that in many countries, such as Brazil, Hong Kong, South Korea, and India, nonbank providers are becoming stronger and dominant. 65 percent of consumers surveyed use third-party platforms for payments. In countries such as China, the number is greater than 95 percent of survey respondents [17]. 
To summarize the literature accessed by the author, Figure 2 puts a theoretical framework to show the areas where platform players are disrupting traditional players. Based on the literature review, it can be said that the platform players are disrupting traditional players in various ways as shown below.

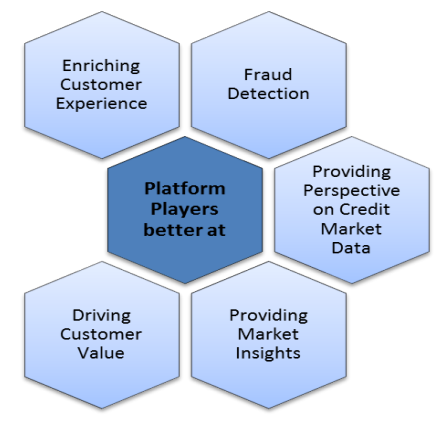

Figure 2: Areas where Platform Players are Disrupting Traditional Players.

\section{LIMITATIONS OF THE CURRENT STUDY}

There's not comprehensive data in the literature reviewed to conclude that platform players are eating into the revenues of traditional players and customers are switching from traditional to platform players. Also, the disruption may not be across the value chain. Marketing, Client Service, Trading and Investments and support functions such as admin are likely to be impacted the most. As per the available literature accessed by the author, most researchers suggest that traditional firms need to create an ecosystem of partners, which may include FinTech to survive the onslaught of platform players.

The present study puts a structure in place for a more exhaustive study in future. The author proposes to use the following model (Table 2) for further study. During the course of a more detailed study, the model will be tested.

\begin{tabular}{|c|c|c|c|}
\hline $\begin{array}{l}\text { Dimensions of Platform- } \\
\text { based Models }\end{array}$ & Explanation & $\begin{array}{l}\text { Impact on Banking and } \\
\text { Financial Services } \\
\text { (High/Low) }\end{array}$ & $\begin{array}{l}\text { Impact Area } \\
\text { (Revenues, Profitability, } \\
\text { Customer Acquisition) }\end{array}$ \\
\hline Customer Service & $\begin{array}{l}\text { Personalized product/ service } \\
\text { offering using data and analytics } \\
\text { - An integrated platform provides } \\
\text { consistent user experience across } \\
\text { channels }\end{array}$ & & \\
\hline Regulator & $\begin{array}{l}\text { - Seamless communication related } \\
\text { to fraud with the regulator } \\
\text { - High ability to manage risk } \\
\text { (operational, financial, and } \\
\text { reputational) and regulation }\end{array}$ & & \\
\hline Internal & $\begin{array}{l}\text { Use of analytics for measurement and } \\
\text { management of credit risk, } \\
\text { operational risk, and market risk. }\end{array}$ & & \\
\hline Technology & $\begin{array}{l}\text { Offering m-wallets, e-wallets, data } \\
\text { warehouse, and non-critical } \\
\text { applications on a cloud platform. }\end{array}$ & & \\
\hline Data & $\begin{array}{l}\text { Implementation of best practices of } \\
\text { data governance. }\end{array}$ & & \\
\hline Analytics & $\begin{array}{l}\text { Use of descriptive, predictive, and } \\
\text { prescriptive analytics. }\end{array}$ & & \\
\hline People & $\begin{array}{l}\text { Specialist manpower for digital } \\
\text { implementation programs. }\end{array}$ & & \\
\hline
\end{tabular}

Table 2: Dimensions of Platform-based Models in Banking and Financial Services.

\section{CONTRIBUTION TO CURRENT LITERATURE \\ How will the proposed study contribute to the existing literature on the future of banking and financial services industry? To stay relevant amidst changing customer expectations and the increasing trend of digital banking, traditional players may have to adopt digital technologies, the sooner the better. Banks and financial services providers may have to adopt new technologies such as Big Data, Artificial Intelligence, Cloud Computing, Mobile and Electronic}

Payments, Machine Learning, Blockchain, Robotics, and Cyber Security. They may also need to partner with several fintech companies to develop new technologies to preempt competition in future both from banking and non-banking entities. Having said that, all these imply that the banking and financial services industry may change from what we know it today. 


\section{GLOSSARY}

Disintermediation: Net-based direct interaction removes the role previously enjoyed by financial advisers, brokers and agents in the value chain.

Platform: Broadly defined, platforms bring together producers and consumers in high-value exchanges of information and interactions enhancing value for involved parties and increasing their competitive advantage.

Platform Model: Digital platforms enable third parties to offer products and services or participate as providers. In Platform model, an Orchestrator needs a large customer base and a Participant has to show competitive advantages in products or services.

Platform Banking: A banking platform offers standards for third-party FinTech developers to build products and services. The platform also allows the banks to deliver a unified banking experience.

Banking Value Chain: The banking value chain includes components such as marketing, sales, client service, investment products and transaction.

Vertical Integration: A company owns or controls its suppliers, distributors, or retail locations. Vertical integration requires significant amounts of capital investment.

Platform Integrator: Platform integrators innovate by weaving together products and services seamlessly with thirdparty offerings. They innovate by leveraging open Application Program Interfaces (APIs).

Platform Provider: Platform providers enable other participants in the platform by developing and provisioning end-to-end products and services. They offer core banking "infrastructure" as a service to other participants.

Platform Specialist: Platform specialists focus on specific activities within the business process. Their specialized focus can be technological or functional.

Platform Orchestrators: Platform orchestrators enable the platform, allowing participants and customers to interact and create mutual value. They operate across multiple networks and industry ecosystems.

\section{REFERENCES}

[1] Google set to offer banking current accounts. (2019). BBC News.
[2] Greg Rung, Davide Baldini, Nick Ielpo, Matt Craggs, (2015). The Digital Disruption Battlefield, Oliver Wyman, p. 3-4.

[3] The Future of Financial Services, How disruptive innovations are reshaping the way financial services are structured, provisioned and consumed (2015), World Economic Forum.

[4] Macchi, M., Levi, D. J., \& Westland, S. (2016). Banking Reinvented: Beyond Value Chains to Value Networks. Accenture Strategy.

[5] Urs Gasser, Oliver Gassmann, Thorsten Hens, Larry Leifer, Thomas Puschmann, Leon Zhao, (2017). Digital Banking 2025, Swiss Fintech Innovation Lab.

[6] Miklos Dietz, Matthieu Lemerle, Asheet Mehta, Joydeep Sengupta, Nicole Zhou, (2017), The Phoenix Rises: Remaking the Bank for An Ecosystem World McKinsey Global Banking Annual Review.

[7] Brad B Wallace, Fabrice Albizzati, Vijay Raghavan, (2018), A vision for platform-based banking, EY.

[8] Hans-Jürgen Walter, David Pade, Corin Targan, Thomas von Hohenhau, (2018), Open Banking A platform-based business approach that came to stay, Monitor Deloitte.

[9] Anna Omarini, (2018). The Retail Bank of Tomorrow: A Platform for Interactions and Financial Services. Conceptual and Managerial Challenges, Research in Economics and Management.

[10] Dietz, Miklós, Sengupta, Joydeep, Zhou, Nicole (2018). Banking needs an ecosystem play. McKinsey Quarterly, 00475394, 2018, Issue 1.

[11] Sarah, Nick, Anthony, Marshall, Ramamurthy (2019). The future of banking in the platform economy. Strategy \& Leadership, Vol. 47 Issue 6, p34-42.

[12] Big Tech in Finance: Opportunities and Risks. (2019). Bank for International Settlements (BIS) Annual Economic Report.

[13] Ant Financial's money market fund shrinks to 2-year low. (2019). Financial Times

[14] Sarah Diamond, Nick Drury, Anthony Lipp, Anthony Marshall, Shanker Ramamurthy, Likhit Wagle, (2019). Banking on the Platform Economy, IBM Institute for Business Value.

[15] The last pit stop? Time for bold late-cycle moves, McKinsey Global Banking Annual Review, 2019.

[16] Joydeep Sengupta, Vinayak HV, Violet Chung, Xiang Ji, Ervin $\mathrm{Ng}$, Lingxiao Xiao, Kristy Koh, Celia Chen (2019). The ecosystem playbook: Winning in a world of ecosystems, 2019 , McKinsey \& Company.

[17] Banks in Need of Improvements in Five Key Areas, TellerVision, June 2019, Number 1502.

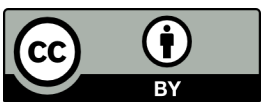

(C) 2020 by the Sanjib Dutta. Submitted for possible open access publication under the terms and conditions of the Creative Commons Attribution $\left(\begin{array}{lll}C & B Y\end{array}\right)$ license (http://creativecommons.org/licenses/by/4.0/). 